\title{
Rhizopus oryzae AM16; a new hyperactive L-asparaginase producer: Semi solid-state production and anticancer activity of the partially purified protein
}

\author{
SARAH I. OTHMAN ${ }^{1}$, AMAL A.I. MEKAWEY ${ }^{2}$, MOHAMMAD M. EL-METWALLY ${ }^{3}$, SAMI A. GABR $^{4}$, \\ MAHA ABDULLA ALWAELE ${ }^{1}$, HAIFA AL FASSAM ${ }^{1}$, RASHA ABO-ELENEEN ${ }^{5}$, \\ AHMED A. ALLAM ${ }^{5}$ and WESAMELDIN I.A. SABER ${ }^{6}$
}

\footnotetext{
${ }^{1}$ Department of Biology, Faculty of Science, Princess Nourah Bint Abdulrahman University, Riyadh 11671, Saudi Arabia;

${ }^{2}$ The Regional Center of Mycology and Biotechnology, Al-Azhar University, Cairo 11765;

${ }^{3}$ Botany and Microbiology Department, Faculty of Science, Damanhour University, Damanhour 22511;

${ }^{4}$ Department of Anatomy and Embryology, Faculty of Medicine, Mansoura University, Mansoura 35511;

${ }^{5}$ Zoology Department, Faculty of Science, Beni-Suef University, Beni-Suef 62511;

${ }^{6}$ Microbial Activity Unit, Department of Microbiology, Soils, Water and Environment Research Institute, Agricultural Research Center, Giza 12619, Egypt
}

Received July 31, 2021; Accepted December 2, 2021

DOI: $10.3892 / b r .2022 .1498$

\begin{abstract}
The demand for L-asparaginase is predicted to increase several fold in the future due to its potential clinical applications in the treatment of lymphoid system malignancies and leukemia. Thus identifying suitable sources of production should be considered high priority. Fungi are valuable organisms as they are able to convert what would be considered 'useless' materials into materials that have potential value. The present study provides a proof of concept of production of a new hyperactive L-asparaginase producer (Rhizopus oryzae AM16), which was successfully isolated and sequentially optimized using a semi solid-state fermentation method with a simple and cheap medium produced from wheat bran (WB). The fungus was able to produce an appreciable amount of the enzyme (2,875.9 U) after 8 days of incubation under $85.7 \%$ moisture, in the presence of magnesium nitrate $(5.0 \mathrm{mg} \mathrm{N} / \mathrm{mg}$ nitrogen per gram of dry WB) at $\mathrm{pH} 5.8$. Testing the anticancer activity confirmed the ability of the resultant enzyme to inhibit the growth of various types of cancer cells (HepG2, MCF-7, HCT and A549). The $\mathrm{IC}_{50}$ values of the dialyzed enzyme were lower than that of the crude product. Thus, this newly identified and purified L-asparaginase may be a promising anticancer drug.
\end{abstract}

Correspondence to: Dr Sami A. Gabr, Department of Anatomy and Embryology, Faculty of Medicine, Mansoura University, Mansoura 35511, Egypt

E-mail: dr.samigabr@gmail.com

Key words: fermentation, fungi, tumor, leukemia, cancer cell

\section{Introduction}

Typically, healthy body cells grow and divide under restricted conditions to form new cells to match the body's needs. All types of cancer however, exhibit continual uncontrolled division of the cell, and this may occur almost anywhere in the human body, with the potential to spread to other regions. Several types of cancer form solid masses of tissue (tumors); however, cancers of the blood, such as leukemias, are an exception $(1,2)$. The amino acid L-asparagine, is required for the survival of both normal and cancer cells. Normal cells can synthesize L-asparagine in amounts sufficient for their metabolic activities, but tumor cells depend mainly on an exogenous supply of L-asparagine (3). L-asparaginases (L-asparagine amidohydrolase; EC 3.5.1.1) catalyzes the breakdown of the amide group of the sidechain of L-asparagine into aspartic acid and ammonia (4), reducing its concentration, which is why regulating $\mathrm{L}$-asparaginases is a cornerstone of the treatment protocols for acute lymphoblastic leukemia (2).

For several years, $\mathrm{L}$-asparaginases have been broadly used for the treatment of lymphoid systems malignancies, childhood acute lymphoblastic leukemia, Hodgkin's lymphoma, lymphosarcoma, and melanosarcoma (5). Apart from its clinical use, $\mathrm{L}$-asparaginases have been used as a diagnostic biosensor for L-asparagine, due to the large amounts of ammonia produced by the enzymatic reaction and its direct correlation with the level of L-asparagine in a patient's blood (6). L-asparaginases have also been characterized successfully as inhibitors of the formation of acrylamide in heated food (7).

L-asparaginase is widely present in several organisms, including plants, animals and microbes, but not in humans. Microbes are the best source for the production of enzymes, including L-asparaginase, as they are easy to cultivate and manipulate (5). Microbes can produce several 
different types of asparaginases that differ in their cellular location and properties; namely periplasmic asparaginase, extracellular asparaginase, intracellular asparaginase and glutaminase-asparaginase, which all play a role in basic metabolism (8).

In contrast to asparaginases obtained from fungi, the longstanding use of bacterial L-asparaginases can cause toxicity and hypersensitivity reactions, leading to anaphylaxis. This may suggest that fungal asparaginases are more closely related to those present in humans, as fungi are eukaryotic microorganisms. Thus the chances of adverse effects and immunological reactions against fungal L-asparaginases are expected to be lower (8). Another advantage of fungal asparaginases is that they are produced extracellularly, and thus it is considerably easier to separate and purify $(4,8)$. Owing to these advantages, fungi are considered to be the most suitable organisms for production of L-asparaginase, and therefore, the search for novel fungal producers is very important.

The utilization of agro-industrial-based products has become of increasing importance in bio-industries, due to the high nutrient content and low-cost (9-11). Wheat bran (WB) as an example, has been reported in the literature for the useful production of value-added biomolecules by fermentation to reduce both the process cost and the environmental waste (12).

The outer pericarp layer of WB, left as a by-product after wheat grain milling, forms $13-17 \%$ of the entire organism (13). WB is rich in minerals (such as iron, zinc, manganese, magnesium and phosphorus), Vitamin-B complex and bioactive compounds (such as phytic acid, ferulic acid and vitamin E) (14). A total of $34-63 \%$ of the WB is formed of soluble and insoluble dietary fibers, a complex compound made of edible plant polysaccharides (cellulose, hemicelluloses and pentosan polymers) attached to proteins (15.2-16.9\%), lignin and other substances $(15,16)$, such as lipids $(5.5-5.6 \%)(17)$. The high nutritional value of WB makes it superior to other agro-industrial candidates for enzyme production. Therefore, it was used in the present study as a source of nutrient and physical support during enzyme production.

Based on the consistency, culture media is classified into one of three types; solid, semi-solid and liquid medium. Solid-state fermentation (SSF) is defined as any fermentation process where the growth of microorganisms takes place on a solid substrate in the absence of free water. With SSF it is possible to utilize renewable and low-cost natural resources (18). However, when plants or crop residues with low water and high sugar and nutrient contents are utilized for SSF, the availability of its constituents may be low or microbial growth may be inhibited, resulting in low system productivity. Therefore, the SSF system was been modified by increasing the water content to increase sugar and nutrient availability. This system of semi-SSF ensures easier growth of fungi and a higher efficiency of the biosynthetic process (19). Identification of a new and affordable hyper-producer of L-asparaginases with fewer adverse effects is of the utmost priority and a considerable challenge for biotechnologists. Hence, in the present study, WB was used for fermentation of Rhizopus oryzae AM16 as a novel source of L-asparaginase grown under semi-SSF conditions, and the anticancer activity of the fungal enzyme was assessed.

\section{Materials and methods}

Chemicals. All chemicals used in the present study were of analytical grade and were obtained from Sigma-Aldrich; Merck KGaA unless otherwise stated. WB was utilized as a solid substrate during the fermentation process, and was kindly provided by the South Cairo and Giza Mills Company.

Cell lines. In the present study, four tumor cell lines, HepG2 human liver cancer cells, MCF-7 breast cancer cells, HCT colon carcinoma cells and A549 lung carcinoma cells were obtained from Vacsera, Co. To ensure the authenticity of the cells used, all cell lines used were confirmed using short Tandem Repeat DNA profiling as previously described (20).

Sampling sites. Soil samples were collected from two Governorates in Egypt; three form the Al Gharbia governorate, including from two sites of cultivated soil, (Al-Dalgamon, N"22.67'3048 E"22.37'3050; Tanta, N"40.77'3047 E"59.94'31 00 ; and one sample obtained from soil contaminated with oil, the Oil \& Soap Company, N"20.82'30 49 E"37.58'3049).

Soil from a total of five sites in the Al-Behira governorate, including three cultivated soil sites (Al-Delengat, N"31.94'30 49 E"49.36'30 32; and two sites from Itay

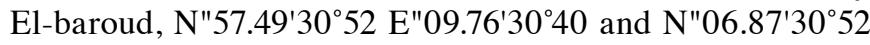
E"41.94'30³9), a non-cultivated site (Shubrakhit, N"55.38'31 $01 \mathrm{E}^{\prime \prime} 34.20^{\prime} 30^{\circ} 42$ ) and one site from soil contaminated with oil obtained from Al-Delengat (N"20.82'30 49 E"37.58'3049) were obtained in the present study.

Air-borne fungi were isolated from the same sites by opening a Petri dish containing sterilized Czapek-Dox agar plates for $\sim 30 \mathrm{~min}$ in the open air, then incubated for 7 days at $28 \pm 2^{\circ} \mathrm{C}$.

Fungal isolation and screening of L-asparaginase activity. Fungi were isolated on modified Czapek-Dox agar plates composed of (in $\mathrm{gl}^{-1}$ ) agar powder supplemented with L-asparagine $\left(10.0 \mathrm{gl}^{-1}\right)$ and $3 \mathrm{ml} / 12.5 \%$ phenol red dye as an indicator (21). Plates were incubated at $28 \pm 2{ }^{\circ} \mathrm{C}$ for 3-5 days. Developed fungal isolates surrounded by a pink zone were selected and grown on potato dextrose slants. Fungal colonies isolated in the previous step were descriptively screened for L-asparaginase capability using a rapid plate assay, as described below. A 5-mm fungal mycelial plug was inoculated onto the modified Czapek-Dox's agar in triplicates.

All plates were incubated at $28 \pm 2^{\circ} \mathrm{C}$ for 3-5 days. Positive asparaginolytic fungi were detected on the yellow-colored medium based on the appearance of a pink zone around the fungal colony, indicating L-asparaginase activity due to the change in color of the phenol red indicator. The diameter of the pink zone was measured and used to compare fungal isolates.

Identification of fungal isolates. For determination of morphological structures, portions of fungal growth were mounted in lactophenol cotton blue stain on clean slides, and the prepared slide was examined under a light microscope at $\mathrm{x} 40$ and x100 magnification for vegetative mycelium; septation, diameters, conidiophores (sporangiophores) and the 
reproductive structures, conidia and sporangiospores amongst others. Fungal colonies were examined at x10 magnification. The colony size, texture and color of the colonies were assessed. The fungal genera and species were identified according to their cultural properties, using morphological and microscopical screening as described previously (22-27).

Culturing technique and the assessed parameters. The semi SSF was performed using WB. Unless otherwise specified, the fermentation medium of L-asparaginase production was composed of $1 \mathrm{~g} \mathrm{WB}$, moistened with $1 \mathrm{ml}$ distilled water placed in $250 \mathrm{ml}$ Erlenmeyer flasks to yield a 1:1 (w/v) growth medium. The medium was sterilized by autoclaving for $15 \mathrm{~min}$ and inoculated with $1 \mathrm{ml}$ fungal spore suspension ( $1 \times 10^{6}$ spores), such that the moisture content was equivalent to $66.7 \%$. Next, inoculated batch fermentation flasks were incubated under static conditions at $28 \pm 2^{\circ} \mathrm{C}$.

The main parameters that were expected to influence the production process were investigated by varying only a single factor at a time, and keeping the remaining factors constant. The studied factors were fermentation time (2-10 days), nitrogen source at $2.5 \mathrm{mg}$ nitrogen per gram of dry WB (gds), and its concentration (based on the nitrogen-equivalent), the WB to water ratio $(1: 2,1: 4,1: 6,1: 8$ and 1:10, w/v) and, finally, the moistener $\mathrm{pH}$, using citrate phosphate buffer (3.0-5.4) and sodium phosphate buffer ( $\mathrm{pH}$ 5.8-7.8).

Extraction of L-asparaginase. After incubation, enzyme extraction was performed by adding $10 \mathrm{ml}$ sodium phosphate buffer ( $\mathrm{pH} 7)$ to the fermented substrate to a final volume of $20 \mathrm{ml}$ to attain an equivalent volume in each of the different flasks, shaken for $30 \mathrm{~min}$ on a rotary shaker at $200 \mathrm{rpm}$ and filtered through a Whatman No. 1 filter paper (Whatman plc; GE Healthcare Life Sciences). The filtrate was then centrifuged at $1,500 \mathrm{xg}$ and $4^{\circ} \mathrm{C}$ for $15 \mathrm{~min}$.

Quantitative assay of L-asparaginase activity. The resultant extraction was assayed for L-asparaginase activity by quantifying ammonia formation spectrophotometrically using Nessler's reagent as described previously (28). One unit (U) of L-asparaginase is expressed as the amount of enzyme per gram of WB dry substrate that catalyzes the formation of one $\mu$ mol ammonia per min under the assay conditions. A standard curve was prepared with ammonium chloride.

Partial purification and protein estimation. The crude Rhizopus oryzae AM16 L-asparaginase, obtained after fermentation at the optimum conditions, was precipitated by adding ammonium sulfate with constant stirring until $80 \%$ saturation was achieved, and was then incubated overnight at $4^{\circ} \mathrm{C}$ to ensure that the precipitation had completed. The precipitate was separated by centrifugation at $2,100 \mathrm{x}$ g for $30 \mathrm{~min}$ at $4^{\circ} \mathrm{C}$. The protein precipitate was resuspended in $0.01 \mathrm{M}$ Tris- $\mathrm{HCl}$ buffer ( $\mathrm{pH}$ 7.2) and dialyzed overnight against the same buffer. The concentration of protein was estimated using a Bradford assay (28), with BSA as the standard. The specific activity is defined as the units of L-asparaginase per $\mathrm{mg}$ of protein.

Cell viability assay. MTT assays were used to assess the two L-asparaginase preparations (crude and dialyzed), to determine their cytotoxic effects against four tumor cell lines: HepG2, MCF-7, HCT and A549 carcinoma cell lines.

When the cells reached $75-90 \%$ confluence, usually $24 \mathrm{~h}$ after passaging, the cell suspension was prepared in complete growth medium (RPMI) supplemented with $50 \mathrm{mg} / \mathrm{ml}$ gentamycin. Aliquots of $100 \mu \mathrm{l}$ cell suspension $\left(1 \times 10^{5}\right.$ cells $\left./ \mathrm{ml}\right)$ were added to each well of a 96-well tissue culture plate. The blank wells contained complete RPMI medium in place of cell suspension.

The cells were incubated for $24 \mathrm{~h}$ at $37^{\circ} \mathrm{C}$ in a humidified incubator with $5 \% \mathrm{CO}_{2}$. After the formation of a complete monolayer cell sheet in each well of the plate, the enzyme (crude and dialyzed) was added in concentrations ranging from 15.63-500 $\mu \mathrm{g} / \mathrm{ml}$. Serial two-fold dilutions of the samples were added into a 96-well tissue culture plate using a multichannel pipette. After $24 \mathrm{~h}$, the culture supernatant was replaced with fresh medium. Next, the cells were incubated at $37^{\circ} \mathrm{C}$ with $100 \mu \mathrm{l}$ MTT solution $(5 \mathrm{mg} / \mathrm{ml})$ for $4 \mathrm{~h}$. Subsequently, the MTT solution was removed and $100 \mu \mathrm{l}$ DMSO was added to each well. The absorbance was detected at $570 \mathrm{~nm}$ using a microplate reader (Tecan Group, Ltd.). The absorbance of untreated cells was considered as $100 \%$. The experiments were repeated three times, independently the percentage of cell viability was calculated. The tested sample was, then, compared using the half-maximal inhibitory concentration $\left(\mathrm{IC}_{50}\right)$ value: The concentration of an individual compound leading to $50 \%$ cell death that was estimated from graphical plots of viable cells vs. enzyme concentrations (28-32).

Statistical analysis. Data are presented as the mean \pm standard deviation of at least three replicates. Statistical analysis was performed using CoStat version 6.4 (CoHort Software).

\section{Results}

Isolation and screening of L-asparaginolytic fungi. L-asparaginase-producing fungi were isolated from the soil and air on modified Czapek-Dox agar plates supplemented with L-asparagine as a sole nitrogen source. Fungi were screened for L-asparaginase potential using a rapid plate assay, and were detected based on the presence of a pink zone around the fungal colony. Isolates that showed the largest diameter pink zones were selected (data not shown). The developed pink color on the yellow-colored medium indicates L-asparaginase activity, as $\mathrm{NH}_{3}$ is liberated, and this changes the phenol red color to pink (21). The highest positive asparaginolytic fungi were chosen and identified. Based on the growth characteristics and morphological features, 4 isolates, with the highest qualitative L-asparaginase in the plate assays were obtained: Aspergillus flavus, Penicillium expansum, Rhizopus oryzae AM16 and Trichoderma viride.

Time vs. L-asparaginase production. The time profile of $\mathrm{L}$-asparaginase biosynthesis of the four fungi was explored for extended time periods of up to 10 days on the WB-based medium (Fig. 1). The time course of enzyme production differs between fungal species depending on the cultivation conditions and the physiological properties of each specific species.

Another purpose of this current test was to select the most active asparaginolytic fungus for further investigation. The 
results showed that L-asparaginase started to accumulate after two days of fermentation, and there were detectable levels of L-asparaginase being produced by three of the four fungi, and for Penicilliumexpansum, its asparaginolytic activity appeared after the 4th day. However, maximum L-asparaginase biosynthesis was observed after 10 (Aspergillus flavus), 8 (Penicillium expansum), 8 (R. oryzae AM16) and 6 (Trichoderma viride) days. Notably, $R$. oryzae AM16 was superior to all other tested fungi, recording 1,048.6 U, followed by P.expansum (836.5 U), A. flavus (789.4 U) and finally $T$. viride $(537.8 \mathrm{U})$. Based on these data $R$. oryzae AM16 was chosen for further study of enzyme production.

R. oryzae AM16 was selected as the most active isolate, a representative image of the active isolate is shown in Fig. 2. A pink zone around the fungal colony was clearly visible (Fig. 2A). Colonies of R. oryzae AM16 appeared white initially, becoming brownish with age and grew to $\sim 1 \mathrm{~cm}$ in thickness. The isolates can grow at temperatures between $7-44^{\circ} \mathrm{C}$ with optimum growth at $37^{\circ} \mathrm{C}$. Sporangiospores are straight, pale brown to brown, and grow between $210-2,500 \mu \mathrm{m}$ in length and $5-18 \mu \mathrm{m}$ in diameter (Fig. $2 \mathrm{~B}$ and $\mathrm{C}$ ). The sporangia are globose or sub-globose, wall spinous and black when mature, and $60-180 \mu \mathrm{m}$ in diameter. The columellae are globose, sub-globose. Sporangiospores are elliptical, globose or polygonal, they are striated and grow 5-8 $\mu \mathrm{m}$ in length. The chlamydospores are abundant, globose, ranging in 10-24 $\mu \mathrm{m}$ in diameter, elliptical and cylindrical.

Nitrogen source. Various nitrogen sources were added separately, based on the $\mathrm{N}$-equivalent ( $5 \mathrm{mg} \mathrm{N} / \mathrm{gds}$ ), to $\mathrm{WB}$ fermented substrate to study their effects on the accumulation of L-asparaginase. The results in Fig. 3 show that the enzyme biosynthesis by $R$. oryzae AM16 was considerably influenced by the type of nitrogen source. Compared with the control (without nitrogen source), all nitrogen sources were found to suppress enzyme production, based on the lower values of L-asparaginase production with the various $\mathrm{N}$ sources, apart from magnesium nitrate. In comparison to organic nitrogen, the inorganic nitrogen sources enhanced and stimulated the highest production of L-asparaginase; magnesium nitrate (1,086 U) was superior, followed by aluminum nitrate (899) and ammonium chloride (799 U).

Magnesium nitrate concentration. Magnesium nitrate, as the best source of nitrogen, was incorporated in the fermentation medium at various concentrations. The results (Fig. 4) show that different concentrations of magnesium nitrate notably influenced L-asparaginase synthesis. Although there was a marked sharp decline at the initial concentration of magnesium nitrate ( $1 \mathrm{mg} \mathrm{N} / \mathrm{gds}$ ) compared with the control ( $0 \mathrm{mg} \mathrm{N} / \mathrm{gds})$, visible increases in enzyme production $(1,770.8 \mathrm{U})$ were observed with higher concentrations, up to $5 \mathrm{mg} \mathrm{N} / \mathrm{gds}$, before decreasing again when the concentration was increased further. With $5 \mathrm{mg}$ $\mathrm{N} / \mathrm{gds}$, a reduction in L-asparaginase synthesis was observed.

Medium humidity. The humidity of the medium is a determining factor in the production process, even in SSF. Thus, the ratio between the fermented substrate to the available water was explored in the present study, with various ratios

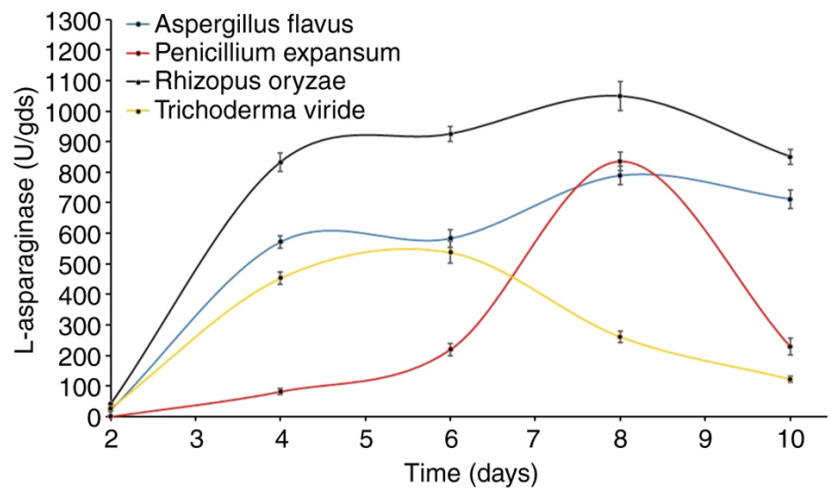

Figure 1. Time course of L-asparaginase production from the selected fungal isolates on wheat bran-based medium without any additional nitrogen sources. The time course of enzyme production differs between fungal species and also based on the cultivation conditions. Thus, the sharp decline may be due to a degree of dryness after long periods of cultivation gds, gram of dry wheat bran.

being investigated (Fig. 5). The results showed that increasing the WB: water ratio to 1:6 (representing $85.7 \%$ moisture) increased the secretion of the L-asparaginase levels gradually to 2,509.6 U. Higher ratios sharply reduced the enzyme levels, although a marked level of the enzyme secretion was still observed.

Culture $\mathrm{pH}$. In the present study, maximal enzyme production was observed at pH $5.8(2,875.9 \mathrm{U})$ as shown in Fig. 6, and production at a $\mathrm{pH}$ higher or lower than this resulted in a decrease in L-asparaginase production by $R$. oryzae AM16. However, the fungus was still able to secrete a reasonable amount of the enzyme in a wide range of $\mathrm{pHs}$ (4.2-7.8).

Anticancer activity. The in-vitro cytotoxic effect of crude and partially purified L-asparaginase on the growth of four types of human tumor cell lines were assessed. Dual incubation of carcinoma cells with various doses of L-asparaginase in the tissue culture medium revealed that the inhibition of human tumor cell lines was dose-dependent. The dialyzed enzyme accomplished its inhibitory effect at lower doses compared with the crude preparation; this trend was true for all the tested cell lines (Fig. 7). The $\mathrm{IC}_{50}$ values of the dialyzed enzyme were 23.4 (HepG2), 72.4 (MCF-7), 23.6 (HCT) and 28.6 (A549) $\mu \mathrm{g} / \mathrm{ml}$. It is hypothesized that the dialysis process concentrated the enzyme protein without adverse impact on its activity and performance. All cell lines were found to be sensitive to the dialyzed protein, the sensitivity of cell lines in descending order are HepG2 > HCT > A549 > MCF-7. However, this order varied when using the crude protein, the HepG2 and HCT cells were the most affected by both the crude and dialyzed enzyme.

\section{Discussion}

Several microorganisms, such as bacteria, yeasts, molds and filamentous fungi, have been reported to produce L-asparaginase. Asparaginases of microbial origin have been shown to be more stable than those from animal and plant sources. Despite bacteria being the primary source of 


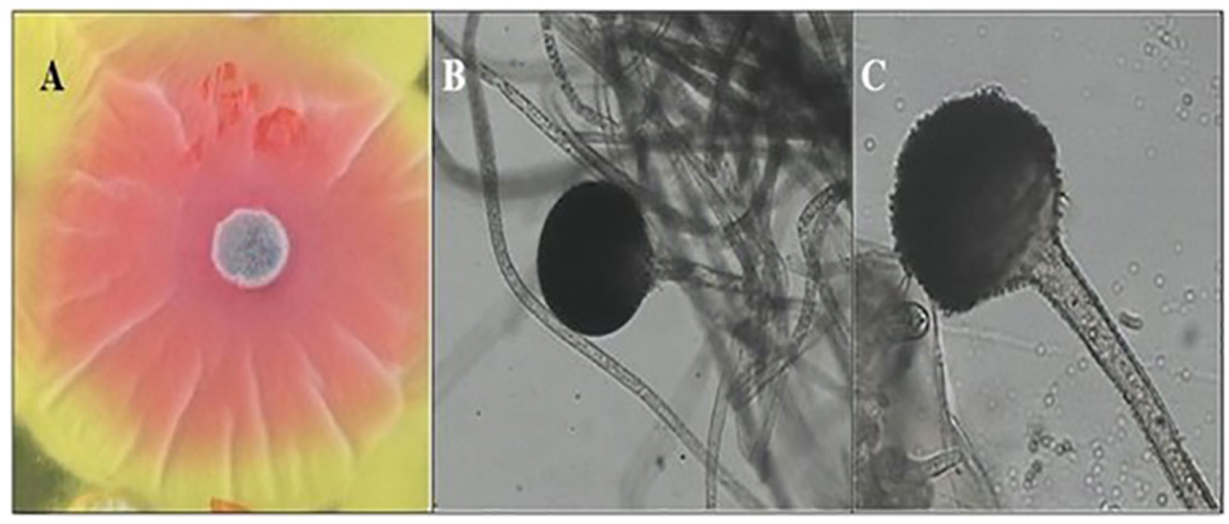

Figure 2. A reverse plate of the active asparaginolytic Rhizopus oryzae AM16, (A) showing the pink zone on the plates, using light microscopy (magnification, $\mathrm{x} 25$ ), of a (B) sporangium surrounded by fungal mycelia and a single sporangiophore bears (magnification, x100), and (C) one sporangium (magnification, x100).

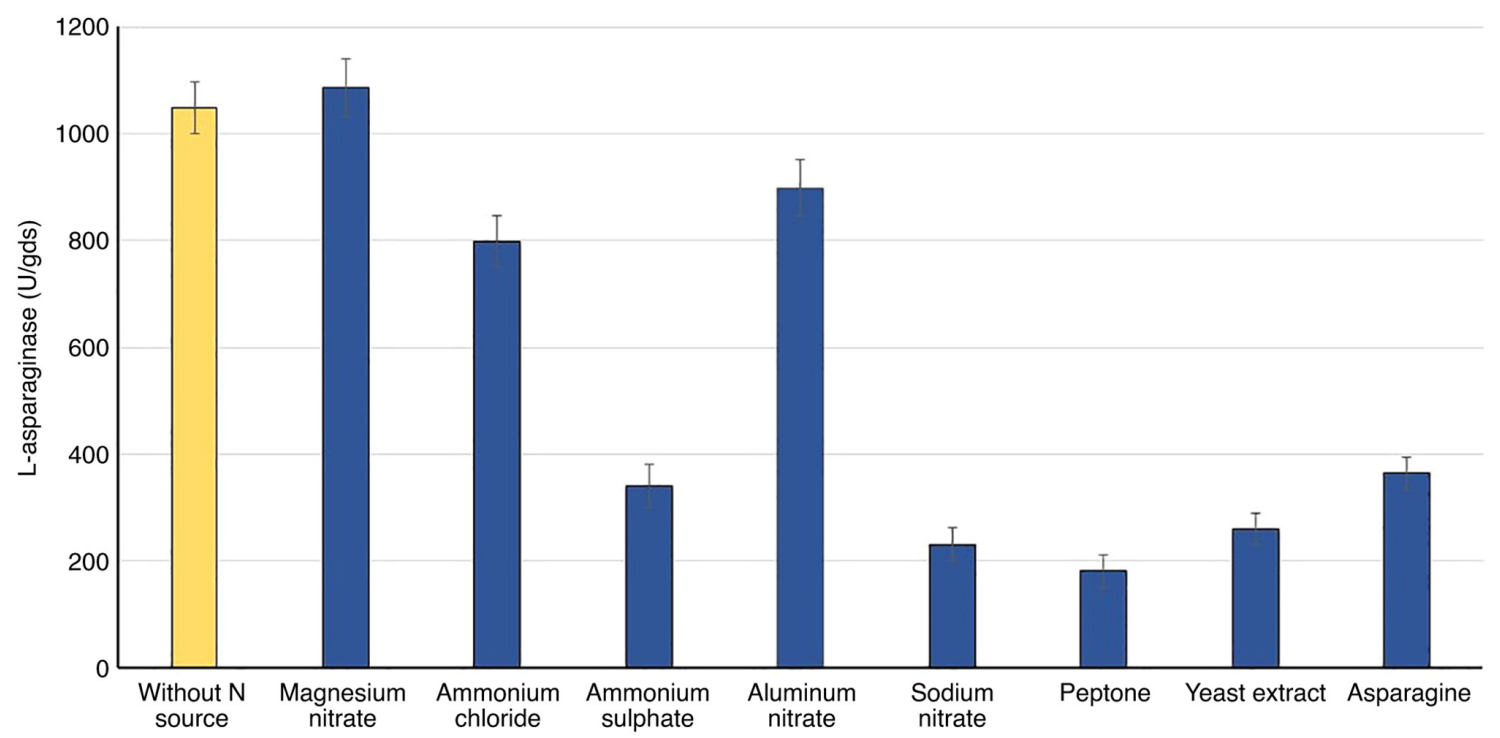

Figure 3. Nitrogen source (2.5 mg N-equivalent/gds) vs. L-asparaginase production by Rhizopus oryzae AM16 after 8 days of fermentation on wheat bran. gds, gram of dry wheat bran.

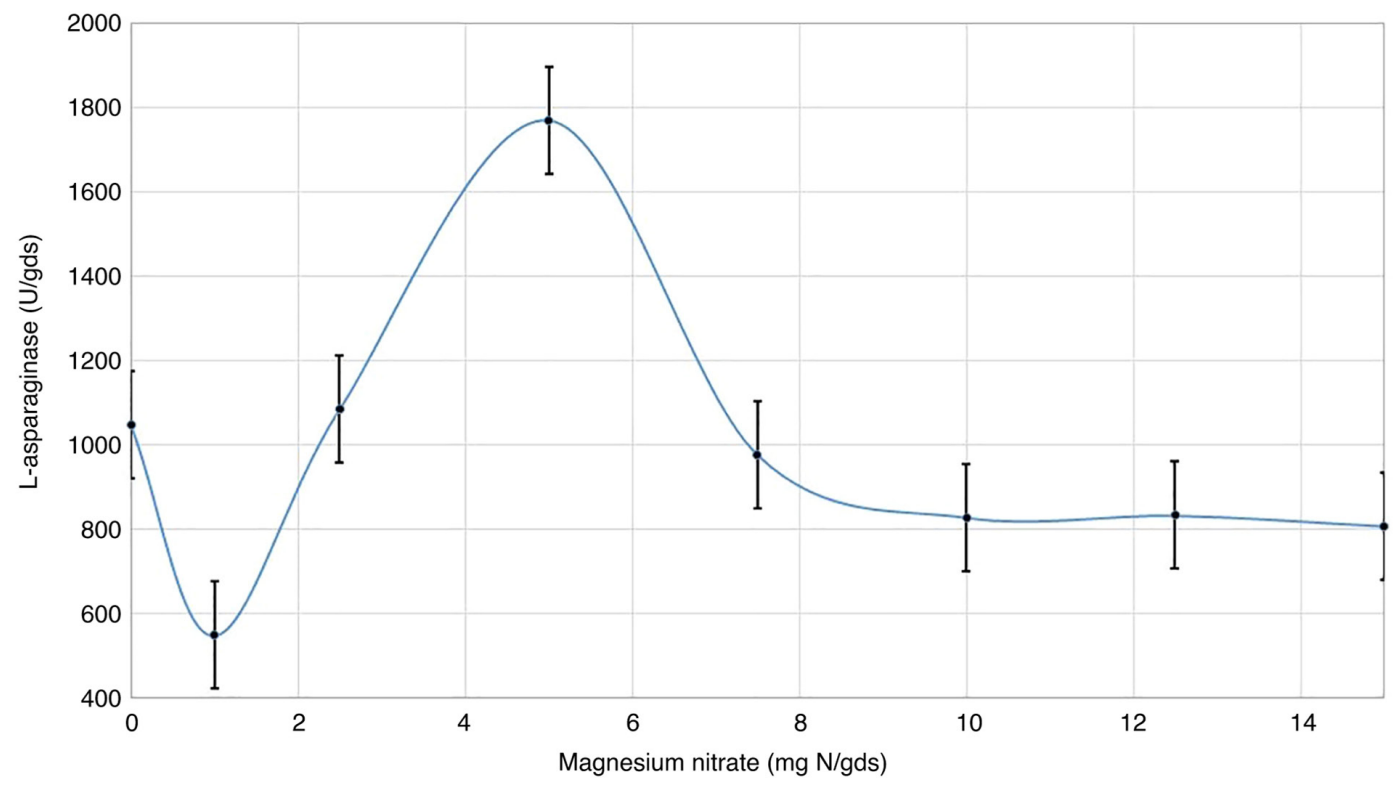

Figure 4. Effect of various concentrations of magnesium nitrate on L-asparaginase production by Rhizopus oryzae AM16 after 8 days of fermentation. gds, gram of dry wheat bran. 


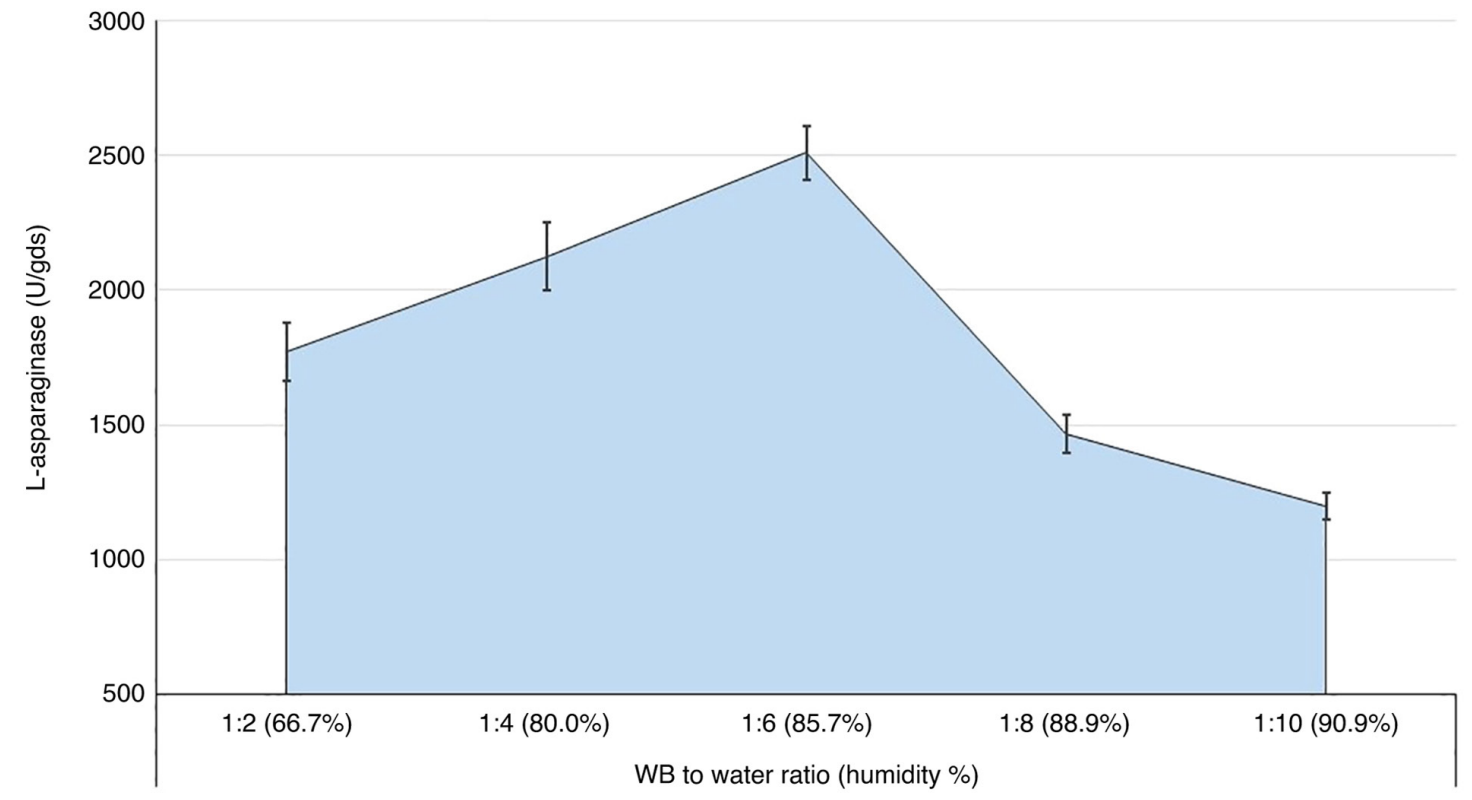

Figure 5. Effect of medium humidity on enzyme production by Rhizopus oryzae AM16 after incubation for 8 days in the presence of $5 \mathrm{mg} \mathrm{Mg}\left(\mathrm{NO}_{3}\right)_{2} \cdot \mathrm{H}_{2} \mathrm{O} / \mathrm{gds}$, based on N-equivalent. gds, gram of dry wheat bran.

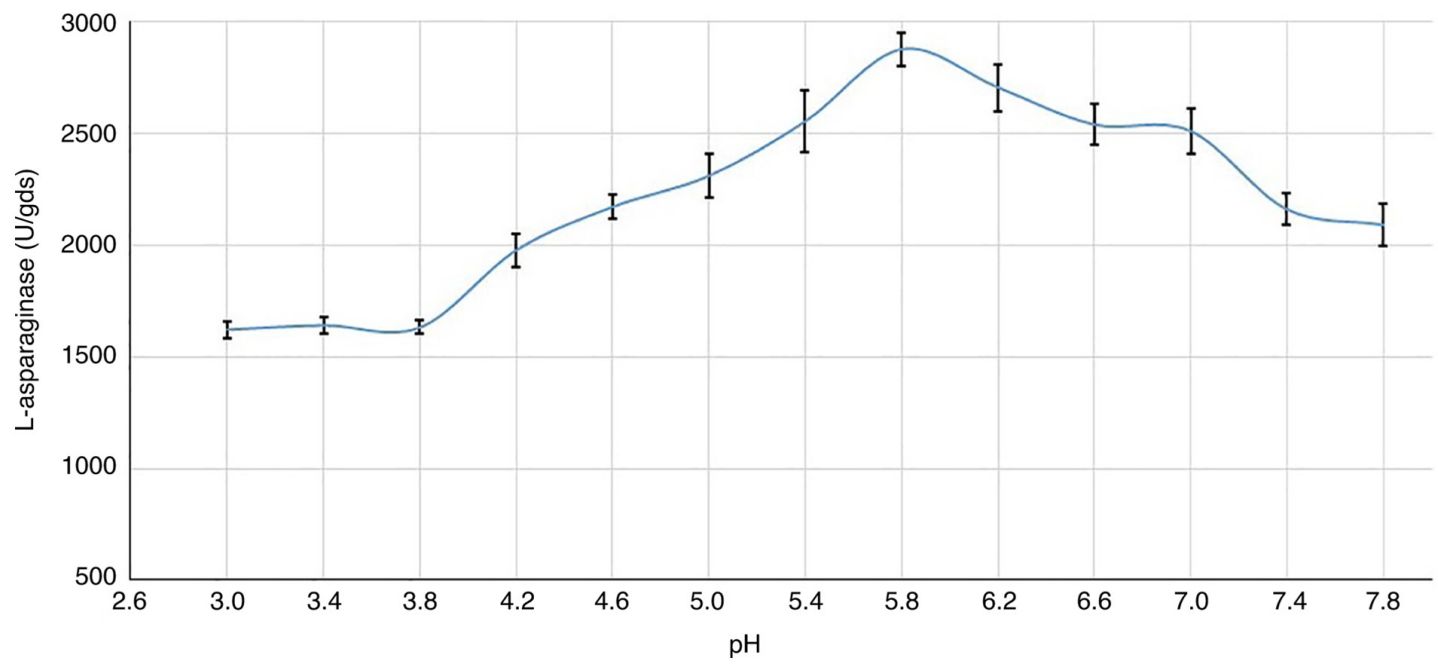

Figure 6. L-asparaginase production by Rhizopus oryzae AM16 in the semi solid-state fermentation medium (85.7\% humidity) in relation to the pH of the culture after incubation for 8 days in the presence of $5 \mathrm{mg} \mathrm{Mg}\left(\mathrm{NO}_{3}\right)_{2} \cdot \mathrm{H}_{2} \mathrm{O} / \mathrm{gds}$, based on N-equivalent gds, gram of dry wheat bran.

L-asparaginase, the enzymes obtained from them have been shown to possess several adverse side effects. Therefore, identifying a novel source of asparaginases is of utmost importance for both clinical and biotechnology purposes. Of the microbes, the most potent producers of asparaginases are fungi (31). Thus, the aim of the present study was to identify an L-asparaginase producing fungus and determine the optimal fermentation conditions, as well as studying its anticancer activity. For example, positive asparaginolytic fungi were found to exist in marine environments and endophytes of seaweed, belonging to the Alternaria, Chaetomium, Cladosporium, Colletotrichum, Curvularia, Nigrospora, Paecilomyces, Phaeotrichoconis, Phoma and Pithomyces genera (32). Moreover, terrestrial endophytic fungi with positive asparaginolytic activity of the genus Colletotrichum, Eupenicillium and Talaromyces were also reported (32). Several asparaginolytic fungi, such as Alternaria sp., Aspergillus nidulans, A. niger, A. oryzae, A. tamarii, A. terreus, Cylidrocapron obtusisporum, Mucor sp. and Fusarium roseum have been described $(4,8)$.

The $R$. oryzae AM16 investigated in the present study was isolated from air. To the best of our knowledge, this is the first report to describe the isolation of asparaginolytic fungus from the air. It is also worth mentioning that the fungus was able to secrete L-asparaginase constitutively without the presence of an induction substrate. Although fermentation conditions vary according to the microorganism, the enzyme can be produced constitutively and/or after induction $(21,33)$.

For optimization of production conditions, the incubation period is one of the most critical parameters in microbial fermentation. As a general rule, the majority of the microbial enzymes can only reach maximal production after a certain period of incubation, which allows the culture to grow at a 


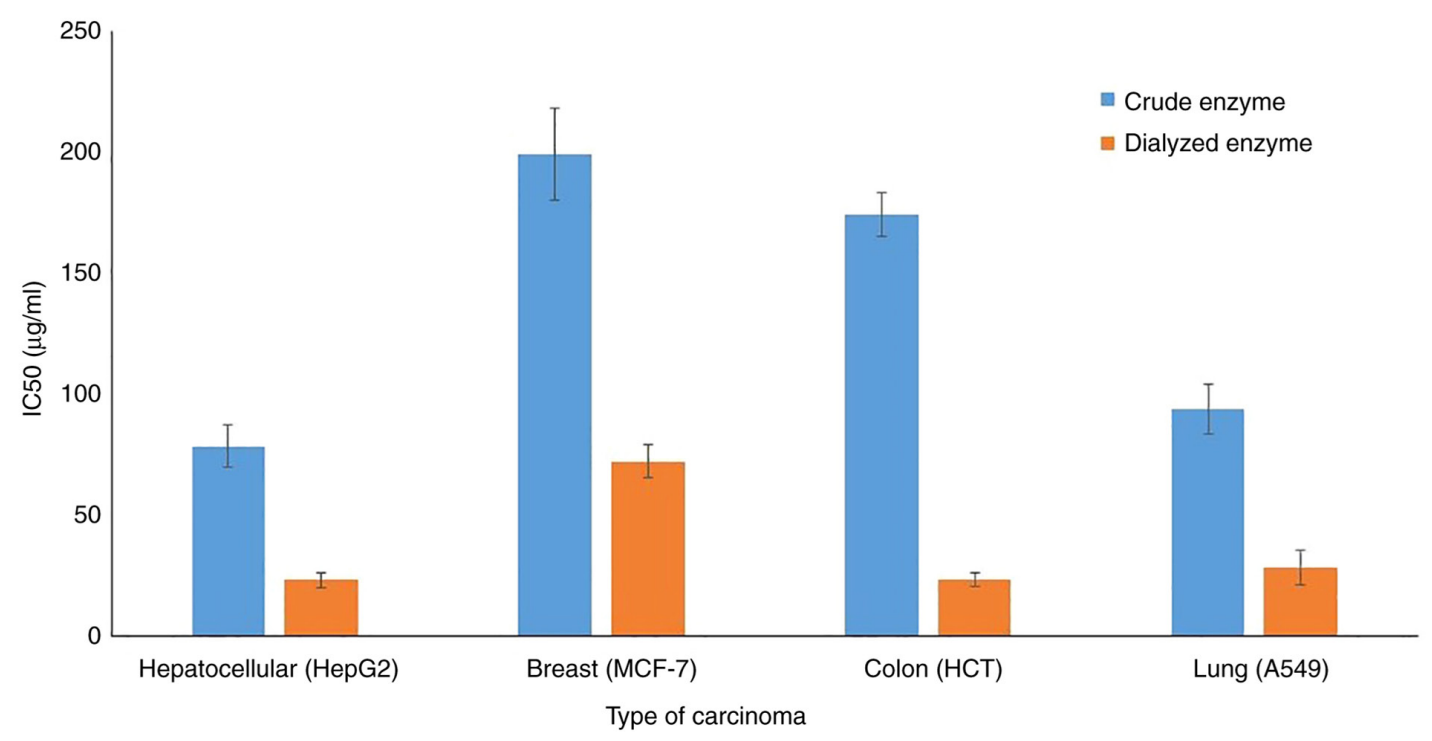

Figure 7. The $\mathrm{IC}_{50}$ value of the crude and dialyzed L-asparaginase from Rhizopus oryzae AM16 on the viability of four different cancer cell lines.

steady state, therefore enzyme production is mostly based on the specific growth rate of the microbe; thus, growth rate and enzyme synthesis are primarily influenced by incubation time (4). Indira et al (31) reported 5 days of fungal incubation for maximum enzyme production (35.72 U). In comparison, the current fungal strain required a longer incubation period (8 days) to reach peak enzyme secretion; however, its L-asparaginase yield was increased by $\sim 30$-fold.

The L-asparaginase from $R$. oryzae AM18 is classified as an extracellular enzyme. Extracellular L-asparaginase is more advantageous than the intracellular counterpart due to the lower production costs, higher degree of accumulation of the enzyme in the culture broth, ease of extraction and purification, and simpler downstream processing methods $(9,34,35)$. Two related families of L-asparaginase have been identified: L-asparaginase, which is a low-affinity enzyme to the substrate, found in the cytoplasm and secreted constitutively, and L-asparaginase II, a high-substrate-affinity periplasmic enzyme that is activated during anaerobiosis (34). L-asparagine was not found to induce enzyme production. A possible explanation is that the enzyme could be induced by its substrate and could also be secreted constitutively $(21,35)$. Conversely, several pieces of literature reported L-asparagine as the most favorable source of nitrogen (4). Other inorganic nitrogen sources, such as ammonium sulfate by A. terreus (31) and sodium nitrate by Fusarium oxysporum (34), showed increased enzyme production. Generally, the presence of additional nitrogen sources alongside the native nitrogenous compounds present in the fermented substrate promotes microbial growth and, consequently, enzyme secretion, since the various kinds of nitrogen (organic and inorganic) are metabolized to various important molecules in the cell, including L-asparaginase (31).

In addition to the nitrogen source, the concentration of the source also has a pronounced influence on enzyme production. The majority of the industrially used enzymes utilize nitrogen sources either in an organic or inorganic form, or sometimes both. The proteinaceous part of the WB is organic, accounting for $15.2-16.9 \%$ of the nitrogen content, consists of $18.6 \%$ glutamic acid and $7.2 \%$ aspartic acid (14), and in several instances, growth is faster when the supply consists of both organic and inorganic nitrogen sources (31). Supporting the fermentation medium with additional inorganic $\mathrm{N}$ in the current study boosted L-asparaginase production by $R$. oryzae AM16. Additionally, the fungus showed slight differences in the production pattern in the presence of nitrogen-free medium.

The obtained enzyme yield was higher than those obtained in previous studies, who reported that inorganic nitrogen sources, particularly ammonium sulfate and sodium nitrate, were preferable for L-asparaginase production by fungi $(27,34)$. However, none of these studies used WB as a substrate, and using cheap agricultural byproducts, such as WB, could be more cost-effective. The composition of WB reflects high nutritional quality; unfortunately, the majority of the minerals (including $\mathrm{P}, \mathrm{Fe}, \mathrm{Zn}$ and $\mathrm{Mg}$ ) in $\mathrm{WB}$ are stored in the form of phytates, forming complexes, which drastically reduce their bioavailability (14). Thus, inorganic nitrogen sources, especially magnesium nitrate, were found to be more favorable than organic sources, in order to compensate for the shortage of elements due to its association with phytates. However, earlier work reported that magnesium nitrate supported favorable growth and fair sporulation of Claviceps microcephala $(36,37)$.

The submerged fermentation technique has been widely used, and is well established for L-asparaginase production, although it carries with it a few disadvantages. Owing to cost-effectiveness, simplicity of the procedure, lower possibility of contamination, ease of recovery of the final bioproducts and lower volume of waste-water generation, SSF has emerged as the preferred technique for bioproduction, particularly when utilizing agro-industrial waste and byproducts (4). The optimum ratio of WB: water (1:6), obtained in the current study, was considered a type of SSF, but with a higher amount of water, in which the free water content had been increased in order to facilitate nutrient availability and fermentation control. Thus, it was termed semi SSF. Similarly, freshly crushed sorghum was used to produce biodiesel under semi SSF of sweet sorghum, and this proved to be a more efficient method (giving yields 9-11\%) than SSF (16). According to Pandey et al (18), the initial moisture content of the solid substrate plays an important role, 
dictating the growth of the organism and enzyme production. A certain quantity of water is essential for generation and synthesis of new cells. Very high moisture levels compacts the substrates and prevents oxygen penetration in the SSF processes, whereas very low moisture content inhibits growth, enzyme activity and accessibility of nutrients (38). Since the low free liquid content binds to and lowers nutrient availability, it restricts fermentation control. However, this also depends on the kind of microorganism being assessed; in the case of fungi, a wider moisture range (20-70\%) supports improved growth and metabolic activities, but for bacteria, only a higher moisture content of the solid matrix can yield better performance $(15-17,38,39)$.

Another determinant factor during the fermentation process is the $\mathrm{pH}$ of the culture. The initial $\mathrm{pH}$ level plays a key role in successful L-asparaginase production. It is well known that growth and metabolism along with enzyme production are regulated by the $\mathrm{pH}$ of the culture, and every organism has its own optimal $\mathrm{pH}$. Any modification in this $\mathrm{pH}$ could result in a negative impact on the enzymatic yield; therefore, $\mathrm{pH}$ was considered a significant issue affecting L-asparaginase biosynthesis $(4,39)$. Contrarily, the majority of previous studies reported that L-asparaginase production tends to be maximized under neutral (31) or alkaline (39) $\mathrm{pH}$ conditions and minimum production was observed at lower $\mathrm{pHs}$. The lower $\mathrm{pH}$ condition for the maximum secretion of the current $R$. oryzae AM16 L-asparaginase suggests the presence of a new variant of the enzyme with unique properties.

Summarizing the fermented substrate; in the SSF process, the selection of appropriate substrate should be based on nutrient value, availability and cost. The solid substrate not only provides nutrients for growth and metabolic activities, but also provides anchorage for microbe growth. WB is considered as the universal agro-industrial substrate for biomolecule production, it has a complete nutritious medium for microorganisms and physically, remains loose even under various conditions of moisture, providing a large surface area (39-41).

Determining the unique biochemical structure of WB showed the presence of high nutritional value of both carbon and nitrogen, in addition to vitamins, mineral salts and other complex components $(11,14)$. Of the carbon present, various soluble sugars such as glucose, xylose, arabinose and galactose were detected, which assist in the initiation of growth and replication of microorganisms, WB has a low lignin content, and relatively more protein content when compared with other agro-industrial substrates (12-14). The balanced biochemical composition of WB makes it a determinant factor for the favored use in microbial growth and enzyme production. This conclusion could be applied in the present investigation, with hypersecretion of L-asparaginase of 2,875.9 $\mathrm{U}$ by $R$. oryzae AM16.

$\mathrm{IC}_{50}$ is commonly used as a measure of antagonist drug potency in pharmacological research, according to the FDA, the $\mathrm{IC}_{50}$ represents the concentration of a drug that is required for $50 \%$ inhibition in-vitro. The lower the $\mathrm{IC}_{50}$, the higher the effectiveness of the drug. Recent medical research on cancer cells has made L-asparaginases and related enzymes potentially key therapeutic tools in the treatment of tumors, suggesting that these protein molecules will most likely be exploited in future clinical applications. L-asparaginase acts on extracellular L-asparagine, reducing its concentration. L-asparagine is a non-essential amino acid, which affects the viability of the cells when its concentration is reduced below the threshold level. Unlike tumor cells, normal cells have the ability to synthesize intracellular L-asparagine using asparagine synthetase. However, the amount of L-asparagine required by a specific cell type will vary, and this explains the differences in the $\mathrm{IC}_{50}$ values observed amongst the four cell types. Moreover, the difference between crude and partially purified proteins on the same cell line may be attributed to differences in the presence of minerals and other components present in each preparation.

Unlike tumor cells, in the case of deficiency, normal cells have the ability to synthesize intracellular L-asparagine, using asparagine synthetase. Neoplastic cells, on the other hand, lack this enzyme and thus require an abundant exogenous supply of L-asparagine for proper growth. In the absence of such a supply of L-asparagine, the levels are rapidly depleted, leading to the death of the neoplastic cells. The depletion of L-asparagine by L-asparaginase from the plasma results in the inhibition of DNA, RNA and protein synthesis, resulting in induction of apoptosis. Therefore, the therapeutic action of L-asparaginase is mediated by depletion of such amino acids from lymphatic tumor cells, resulting in starvation and ultimately death of the cells $(4,6,8)$.

In conclusion, the current study identified a new L-asparaginase with promising anticancer activity on various cancer cell lines. The modest sequential optimization trials for L-asparaginase production by $R$. oryzae AM16 on semi SSF succeeded in inducing the hyperproduction of the enzyme, with a maximum production of 2,875.9 U/gds after 8 days of incubation with $85.7 \%$ moisture, in the presence of magnesium nitrate $(5 \mathrm{mg} \mathrm{N} / \mathrm{gds})$ at $\mathrm{pH} 5.8$. The anticancer activity of the dialyzed enzyme against certain types of cancer cells (HepG2, MCF-7, HCT and A549) was confirmed at low doses.

\section{Acknowledgements}

The authors acknowledge Princess Nourah bint Abdulrahman University Researchers Supporting Project (no. PNURSP2022R5), Princess Nourah bint Abdulrahman University, Riyadh, Saudi Arabia.

\section{Funding}

The present study was funded by the Princess Nourah bint Abdulrahman University Researchers Supporting Project (no. PNURSP2022R5), Princess Nourah bint Abdulrahman University, Riyadh, Saudi Arabia.

\section{Availability of data and materials}

The datasets used and/or analyzed during the present study are available from the corresponding author on reasonable request.

\section{Authors' contributions}

AAIM, MMEM and WIAS conceptualized and designed the study, and performed the experiments. SIO, SAG, MAA, AAA, HAF and RAE analyzed and interpreted the data. SAG, AAA, AAIM, MMEM and WIAS drafted the manuscript. All authors revised the manuscript as well as read and approved the final version. AAIM, MMEM and WIAS confirm the authenticity of all the raw data. 


\section{Ethics approval and consent to participate}

Not applicable.

\section{Patient consent for publication}

Not applicable.

\section{Competing interests}

The authors declare that they have no competing interests.

\section{References}

1. Cooper GM: The development and causes of cancer. In: The Cell: A Molecular Approach. 2nd edition. Sinauer Associates, Sunderland, MA, 2000

2. Ramya LN, Doble M, Rekha VPB and Pulicherla KK: L-Asparaginase as potent anti-leukemic agent and its significance of having reduced glutaminase side activity for bette treatment of acute lymphoblastic leukaemia. Appl Biochem Biotechnol 167: 2144-2159, 2012.

3. Kebeish R, El-Sayed A, Fahmy H and Abdel-Ghany A: Molecular cloning, biochemical characterization, and antitumor properties of a novel L-asparaginase from Synechococcuselongatus PCC6803. Biochemistry (Mosc) 81: 1173-1181, 2016.

4. Naser S, Saber W, El-Metwally M, Moustafa M and El-Kott A Fungal assembly of L-asparaginase using solid-state fermentation: A review. Biocell 44: 147, 2020.

5. Duval M, Suciu S, Ferster A, Rialland X, Nelken B, Lutz P, Benoit Y, Robert A, Manel AM, Vilmer E, et al: Comparison of Escherichia coli-asparaginase with Erwinia-asparaginasein the treatment of childhood lymphoid malignancies: Results of a randomized European Organisation for research and treatment of Cancer-Children's Leukemia Group phase 3 Trial. Blood 99: 2734-2739, 2002.

6. Verma N, Kumar K, Kaur G and Anand S: L-asparaginase: A promising chemotherapeutic agent. Crit Rev Biotechnol 27: 45-62, 2007.

7. Kornbrust BA, Stringer MA, Lange NE, Hendriksen HV, Whitehurst R and Oort MV: Asparaginase-an enzyme for acrylamide reduction in food products. In: Enzymes in Food Technology. 2nd edition, pp59-87, 2010.

8. Batool T, Makky EA, Jalal M and Yusoff MM: A comprehensive review on L-Asparaginase and its applications. Appl Biochem Biotechnol 178: 900-923, 2016

9. Vivekanandha S, Muruganantham S and Paulraj P: Anovel role of L-asparaginase enzyme production from fungal species. J Microbiol Biotechnol Res 3: 7-14, 2013.

10. Thomas L, Larroche $\mathrm{C}$ and Pandey A: Current developments in solid-state fermentation. Biochem Eng J 81: 146-161, 2013.

11. Sreenivasulu V, Jayaveera KN and Rao PM: Solid-state fermentation for the production of L-asparaginase by Aspergillus sp. J Pharmacogn Phytochem 1: 21-25, 2009.

12. Doriya K and Kumar DS: Optimization of solid substrate mixture and process parameters for the production of L-asparaginase and scale-up using tray bioreactor. Biocatalysis Agricultural Biotechnol 13: 244-250, 2018

13. Apprich S, Tirpanalan O, Hell J, Reisinger M, Böhmdorfer S Siebenhandl-Eh S, Novalin S and Kneifel W: Wheat bran-based biorefinery 2: Valorization of products. LWT-Food Sci Technol 56: 222-231, 2014

14. Prueckler M, Siebenhandl-Ehn S, Apprich S, Hoeltinger S, Haas C, Schmid E and Kneifel W: Wheat bran-based biorefinery 1: Composition of wheat bran and strategies of functionalization LWT-Food Sci Technol 56: 211-221, 2014.

15. Andersson AA, Dimberg L, Åman P and Landberg R: Recent findings on certain bioactive components in whole grain wheat and rye. J Cereal Sci 59: 294-311, 2014

16. De Brier N, Hemdane S, Dornez E, Gomand SV, Delcour JA and Courtin CM: Structure, chemical composition and enzymatic activities of pearlings and bran obtained from pearled wheat (Triticumaestivum L.) by roller milling. J Cereal Sci 62: 66-72, 2015.

17. Babu CR, Ketanapalli H, Beebi SK and Kolluru VC: Wheat bran-composition and nutritional quality: A review. Adv Biotechnol Micro 9: 555754, 2018.
18. Pandey A, Soccol CR, Rodriguez-Leon JA and Nigam PSN Solid-state fermentation in biotechnology: Fundamentals and applications. Asiatech Publishers, Inc., New Delhi, 2001.

19. Economou CN, Makri A, Aggelis G, Pavlou S and Vayenas DV: Semi-solid state fermentation of sweet sorghum for the biotechnological production of single cell oil. Bioresource Technol 101: 1385-1388, 2010

20. Reid Y, Storts D, Riss T and Minor L, Markossian S, Grossman A, Brimacombe K, Arkin M, Auld D, Austin CP, et al: Authentication of human cell lines by STR DNA profiling analysis. In: Assay Guidance Manual. Markossian S, Grossman A Brimacombe K, et al (eds). Eli Lilly \& Company and the National Center for Advancing Translational Sciences, Bethesda, MD, 2004

21. Gulati R, Saxena RK and Gupta R: A rapid plate assay for screening L-asparaginase producing micro-organisms. Lett Appl Micro 24: 23-26, 1997.

22. Raper KB, Austwick PK and Fennell DI: The Genus Aspergillus. R.E. Krieger, Malabar, FL, 1977.

23. Pitt JI: The genus Penicillium and its teleomorphic states Eupenicillium and Talaromyces. Academic Press, London and New York, 1979.

24. Pitt JI: A Laboratory Guide to Common Penicillium Species. Commonwealth Scientific and Industrial Research. North Ryde, 1986.

25. Kitch MA and Pitt JI: A laboratory guide to the common Aspergillus species and their Teleomorphs. Published by Commonwealth Scientific and Industrial Research Organization. Division of Food Processing, Sydney, 1992.

26. Kubicek CP and Harman GE: Trichoderma and Gliocladium. Taylor and Francis Ltd., London and Bristol, 1998

27. Domsch KH, Gams W and Anderson TH: Compendium of Soil Fungi. Academic Press, London, 1980.

28. Baskar G and Renganathan S: Production of L-asparaginase from natural substrates by Aspergillus terreus MTCC 1782: Optimization of carbon source and operating conditions. Int J Chem Reactor Engineering: Oct 18, 2011 (Epub ahead of print). doi: 10.1515/1542-6580.2479.

29. Bradford MM: A rapid and sensitive method for the quantitation of microgram quantities of protein utilizing the principle of protein-dye binding. Anal Biochem 72: 248-254, 1976.

30. Cheng YL, Chang WL, Lee SC, Liu YG, Lin HC, Chen CJ, Yen CY, Yu DS, Lin SZ and Harn HJ: Acetone extract of Bupleurum scorzonerifolium inhibits proliferation of A549 human lung cancer cells via inducing apoptosis and suppressing telomerase activity. Life Sci 73: 2383-2394, 2003.

31. Indira K, Jayaprabha N, Balakrishnan S, Arulmoorthy MP and Srinivasan M: Production, purification and characterisation of extracellular L-asparaginase from salt marsh fungal endophytes. J Pharm Pharmac Sci 4: 663-677, 2015.

32. Thirunavukkarasu N, Suryanarayanan TS, Murali TS, Ravishankar JP and Gummadi SN: L-asparaginase from marine derived fungal endophytes of seaweeds. Mycosphere 2: 147-155, 2011.

33. Theantana T, Hyde KD and Lumyong S: Asparaginase production by endophytic fungi from Thai medicinal plants: Cytotoxicity properties. Int J Integrative Biol 7: 1-8, 2009.

34. Ahmad N, Pandit NP and Maheshwari SK: L-asparaginase gene-a therapeutic approach towards drugs for cancer cell. Int J Biosci 2: 1-11, 2012

35. Shakambari G, Ashokkumar B and Varalakshmi $P$ : $\mathrm{L}$-asparaginase-A promising biocatalyst for industrial and clinical applications. Biocatalysis Agricultural Biotechnol 17: 213-224, 2019.

36. Tippani R and Sivadevuni G: Nutritional factors effecting the production of L-asparaginase by the Fusarium sp. Afr J Biotechnol 11: 3692-3696, 2012.

37. Uppuluri KB and Reddy DS: Optimization of L-asparaginase production by isolated Aspergillusniger using sesame cake in a column bioreactor. J Pure Appl Microbiol 3: 83-90, 2009.

38. Singh SB, Bais BS and Singh DR: Effect of different carbon and nitrogen sources on the growth and sporulation of Claviceps microcephal (Wallr.) TUL. Mycopathol Mycol Appl 46: 373-378, 1972.

39. Selvaraj S and Murty VR: Semi-solid state fermentation: A promising method for production and optimization of tannase from Bacillus gottheilii M2S2. Res J Biotechnol 12: 39-48, 2017.

40. Abdel-Fattah YR and Olama ZA: L-asparaginase production by Pseudomonas aeruginosa in solid-state culture: Evaluation and optimization of culture conditions using factorial designs. Process Biochemistry 38: 115-122, 2002.

41. Reid ID: Solid-state fermentations for biological delignification. Enzyme Micro Technol 11: 786-803, 1989.

This work is licensed under a Creative Commons Attribution-NonCommercial-NoDerivatives 4.0 International (CC BY-NC-ND 4.0) License. 